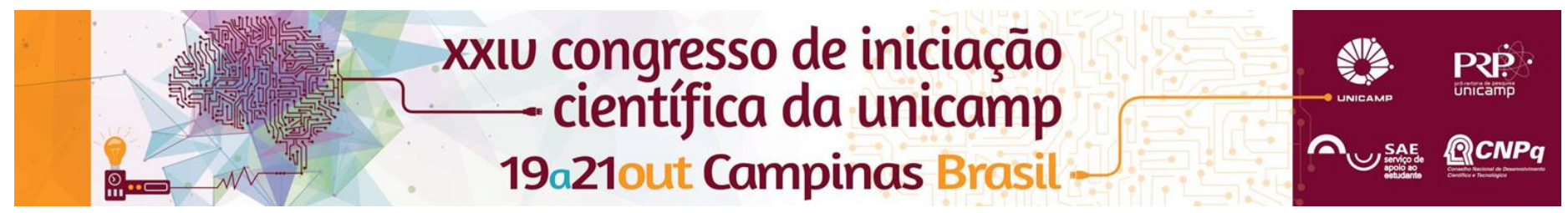

\title{
PESQUISA-IMPLEMENTAÇÃO DE SERVIÇO EDUCATIVO DO “ATELIE DA MORAS” - ATELIÊ DE PRODUÇÃO ARTÍSTICA DA MORADIA DA UNICAMP
}

\section{*Rafael Lucas Cavalheri, Fernanda Maria Macahiba Massagardi.}

\section{Resumo}

A pesquisa teve como objetivo um plano proposta de Serviço Educativo no Ateliê da Moras- Ateliê de Produção Artística da Moradia da Unicamp, cujo resultado do processo foi uma revista on-line sobre os direitos humanos confeccionado por adolescentes da comunidade do Bairro Santa Izabel da cidade de Campinas - SP. A pesquisa foi realizada por meio da metodologia Abordagem Triangular de Ana Mae Tavares Bastos Barbosa e a educação do sensível de Duarte Júnior, tendo os serviços educativos da Fundação Bienal como instrumento de estudo.

\section{Palavras-chave:}

Arte e Educação, Implementação de Serviço Educativo, Ateliê e Comunidade

\section{Introdução}

A partir estudos dos serviços educativos da Fundação Bienal e da Abordagem Triangular de Ana Mae Tavares Bastos Barbosa e a educação do sensível de Duarte Júnior, foi levado a termo a criação do Serviço Educativo no "Ateliê da Moras" - Ateliê de Produção Artística localizado no Programa de Moradia da Unicamp. Entre os resultados obtidos foi elaborada a revista artística do "Ateliê da Moras", cuja temática é referente as questões dos Direitos Humanos. Os participantes foram adolescentes da comunidade dos Bairros Jardim das Américas e Santa Izabel da cidade de Campinas - SP, localizados nas proximidades do Ateliê.

\section{Resultados e Discussão}

O Resultado deste projeto foi uma Revista On-line de Direitos Humanos confeccionada pelos adolescentes particpantes das oficinas, sendo o fundamento as obras do artista Romeno Dan Perchovjschi, participante da $31^{\circ}$ Bienal de São Paulo. A técnica deste artista, na simplicidade do traço dos seus desenhos e na profundidade da abordagem crítica social serviram de base para a fundamentação teórica e prática das reflexões sobre os Direitos Humanos no Brasil. A Revista está disponível na página do facebook do Ateliê da Moras gratuitamente.

Além das "Estratégias de Mediação e a Abordagem Triangular" das pesquisadoras Ana Mae Barbosa e Rejane Coutinho, a metodologia "Pesquisa- Ação" do pesquisador David Tripp também foi aplicada nas atividades projeto.

Por meio de aparelhos celulares, computadores e tablets, os participantes realizaram uma pesquisa com fins curatoriais. Dessa forma, uma primeira discussão da linguagem e das críticas oriundas dos trabalhos do artista aconteciam culminando em uma próxima etapa prática de confecção de desenhos sobre os direitos humanos.

Os participantes representaram suas ideias $e$ posteriormente pesquisavamos sobre o que são os direitos humanos. Uma nova discussão surgia e os participantes produziam novos desenhos, com novos temas e assuntos que antes passavam desapercebido. Também foi utilizada a proposta de David Tripp como metodologia de pesquis-ação, que consiste em uma prática que gera pensamento reflexivo e transformação.

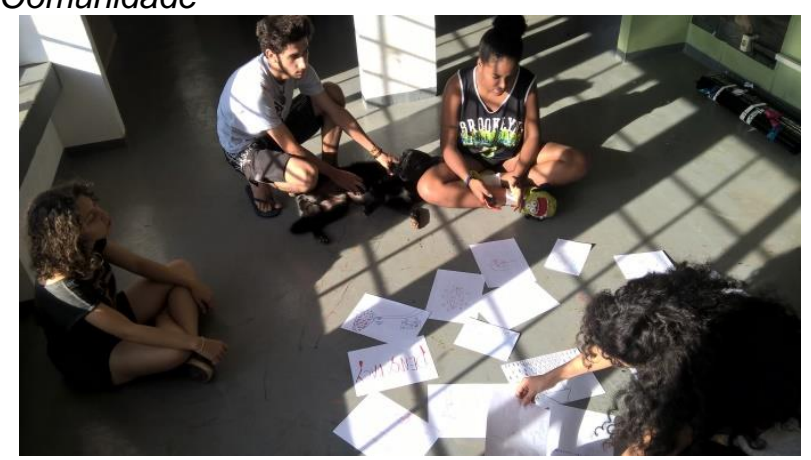

Figura: discussão dos trabalhos com participantes no Ateliê.

\section{Conclusão}

O assunto Direitos Humanos abordado na pesquisa é um tema atual que exige reflexão e engloba questões sócioculturais. Por meio da Arte foi dada aos adolescentes a possibilidade de expor suas convicções, discutir com os colegas questões relativas à diversidade e relações interpessoais.

A escolha do artista Dan Perchojvschi também foi fundamental para que a elaboração da revista e responder a questão proposta no projeto: a possibilidade de inserir o fazer artístico na vida das pessoas. A tecnica do artista ilustradas no poster - por meio da simplicidade da forma e profundidade dos assuntos criaram uma proximidade com o fazer artítico que rompeu a barreira do "mas eu não sei desenhar".

Dessa forma, os alunos puderam ampliar seu repertório e também perceber que há muitas formas de desenhar $e$ que a Arte é um veículo de grande alcance no que tange a expressão de ideias e convicções.

\section{Agradecimentos}

Agradeço a Fernanda Macahiba pela sensibilidade e as mãos fortes, dadas à mim, na confiança e orientação deste projeto. Ressalto também a CAC - Coord. de Ass.Comunitários da Unicamp e ao CNPQ/PIBIC pelo financiamento do Projeto.

BARBOSA, Ana Mae et al. Arte educação como mediação cultural e social. UNESP, 2008.

COUTINHO, Rejane Galvão. Estratégias de mediação e a abordagem triangular. BARBOSA, AM; COUTINHO, RG Arte/Educação como mediação cultural e social. São Paulo: Editora UNESP, 2009.

JÚNIOR, João-Francisco Duarte; FRANCISCO, João. O sentido dos sentidos: a educação (do) sensível. Criar, 2004. 